Marquette University

e-Publications@Marquette

College of Nursing Faculty Research and

Publications

Nursing, College of

$12-1-2010$

\title{
The Association of Religiosity, Sexual Education, and Parental Factors with Risky Sexual Behaviors Among Adolescents and Young Adults
}

Kristin Haglund

Marquette University, kristin.haglund@marquette.edu

Richard Fehring

Marquette University, richard.fehring@marquette.edu

Accepted version. Journal of Religion and Health, Vol. 49, No. 4 (December 2010): 460-472. DOI. (C) 2010 Springer. Used with permission.

Shareable Link. Provided by the Springer Nature SharedIt content-sharing initiative. 


\title{
The Association of Religiosity, Sexual Education, and Parental Factors with Risky Sexual Behaviors Among Adolescents and Young Adults
}

\author{
Kristin A. Haglund \\ College of Nursing, Marquette University \\ Milwaukee, WI \\ Richard J. Fehring \\ College of Nursing, Marquette University \\ Milwaukee, WI
}

\begin{abstract}
:
This study examined the association of religiosity, sexual education and family structure with risky sexual behaviors among adolescents and young adults. The nationally representative sample, from the 2002 National Survey of Family Growth, included 3,168 women and men ages 15-21 years. Those who viewed religion as very important, had frequent church attendance, and held religious sexual attitudes were $27-54 \%$ less likely to have had sex and had significantly fewer sex partners than peers. Participants whose formal and parental sexual education included abstinence and those from two-parent families were $15 \%$ less likely to have had sex and had fewer partners.
\end{abstract}

\section{Introduction}

Helping adolescents and young adults decrease their risky sexual behaviors remains an important health promotion activity. Engaging in genital sexual activities is a risk behavior that has resulted

Journal of Religion and Health, Vol. 49, No. 4 (December 2010): pg. 460-472. DOI. This article is (C Springer and permission has been granted for this version to appear in e-Publications@Marquette. Springer does not grant permission for this article to be further copied/distributed or hosted elsewhere without the express permission from Springer. 
in $\sim 780,000$ pregnancies among girls ages 10-19-years-old of which 30-40\% resulted in induced abortions (Menacker et al. 2004; Ventura et al. 2007). Among sexually active male and female adolescents ages 13-24, 9.1 million sexually transmitted infections and 20,000 HIV infections occurred annually (Weinstock et al. 2004). Various factors have been identified as being protective for young people in terms of helping them to decrease their sexual risks. This study examined how religiosity, formal and parental sexual education, and two-parent families were associated with risky sexual behaviors among adolescents and young adults.

\section{Literature Review}

\section{Religiosity}

A growing body of research indicates that religiosity is a protective factor that appears to contribute to decreased sexual risk behaviors. Broadly, religiosity may be defined as a set of institutionalized beliefs, doctrines and rituals, and ethical standards for how to live a good life (Holder et al. 2000). Most research supported that adolescents who were more religious tended to delay sexual activity (Kirby 2002; Rostosky et al. 2004). For male and female teens, frequent attendance at religious services and religious youth activities, higher levels of importance of religion in daily life and religious feelings, and increased adherence to religious teachings were all significantly related to decreased rates of voluntary sexual debut (Fehring et al. 1998; Holder et al. 2000; Lammers et al. 2000; Lefkowitz et al. 2004; McCree et al. 2003; Nonnemaker et al. 2003; Rostosky et al. 2003). Having increased levels of social support from friends in a faith context was related to decreased likelihood of sexual initiation as was having peers who attended church regularly (Holder et al. 2000; Manlove et al. 2008; Mott et al. 1996). For sexually experienced youths, increased attendance at religious services and participation in organized religious activities were related to decreased frequency of sexual intercourse and noncoital genital behaviors and number of sexual partners (Fehring et al. 1998; Lefkowitz et al. 2004).

Religiosity was related to sexual attitudes. Youths who were more religious had significantly less permissive views regarding premarital sex and endorsed more religious attitudes on sexuality (Fehring et al. 1998; Lefkowitz et al. 2004; Sheeran et al. 1993; 
Thornton and Camburn 1989). However, it was not clear that sexual attitudes influenced sexual behaviors. In two studies, the relationship between attitudes and sexual behaviors was not clearly stated (Fehring et al. 1998; Lefkowitz et al. 2004; Thornton and Camburn 1989) and in one study, religious sexual attitudes were unrelated to sexual behaviors (Sheeran et al. 1993). The current study advanced knowledge in this area by examining the relationship between religiosity and risky sexual behaviors using a nationally representative sample and by overtly examining whether religious sexual attitudes were related to less risky sexual behaviors.

\section{Formal Sexual Education}

In the United States, school-based, formal sexual education has focused largely on either abstinence-only or abstinence-plus in which abstinence education is combined with information on condoms and contraceptives. The efficacy of sexual education to decrease risky sexual behaviors has varied between different approaches and for different demographic groups of youths. Helping youths to delay initiation of intercourse, decrease frequency of intercourse and decrease the number of sexual partners has proven to be difficult. $A$ review of 83 experimental or quasi-experimental studies of curriculum and group-based sex or HIV education programs for young people ages 9-24 years was published recently (Kirby et al. 2007). In 90\% of the reviewed studies, abstinence-plus programs were tested. Seven percent were abstinence-only programs and the remaining $3 \%$ focused only on condoms. A significant delay in initiation of sexual activity for at least 6 months was reported in almost one-half (42\%) of the 52 studies in which timing of sexual initiation was measured. Frequency of intercourse was significantly reduced in one-third (29\%) of the 31 studies that measured frequency of intercourse. Number of partners was significantly reduced in one-third (35\%) of the 34 studies that measured number of sexual partners (Kirby et al. 2007). While some studies reported significant decreases in risky sexual behaviors, nonsignificant results were reported in over half (55-62\%) of the studies. There have been few published program evaluations of abstinence-only projects which explain in part the small number included in Kirby et al.'s review as well as implies that there is insufficient evidence to judge the impact of abstinence-only programs (Young and Penhollow 2006). This study contributes to the debate

Journal of Religion and Health, Vol. 49, No. 4 (December 2010): pg. 460-472. DOI. This article is (c) Springer and permission has been granted for this version to appear in e-Publications@Marquette. Springer does not grant permission for this article to be further copied/distributed or hosted elsewhere without the express permission from Springer. 
regarding formal sexual education by examining the relationships between various models of sexual education and risky sexual behaviors in a nationally representative sample.

\section{Parental Factors}

Parents may exert a protective influence in a variety of ways, two of which include maintaining a two-parent household and educating their children about sexuality. In most studies, living with two parents was found to be protective. Youths who lived with two parents were more likely to either have a later age at sexual debut or remained virginal at the time of the study than their peers who did not live with both parents (Aspy et al. 2007; Blum et al. 2000; Kinsman et al. 1998; Kirby 2002; Lammers et al. 2000; Raine et al. 1999).

Findings regarding the influence of parental sexuality education were mixed. Some researchers found no relationship between initiating intercourse and discussion with guardians about sexual risks (Romer et al. 1999). Conversely, youths who discussed a greater number of sexual topics with their mothers than with friends were more likely to believe that teens should not have sex before marriage and also more likely to be virgins (Dilorio et al. 1999). The number of topics discussed with fathers was not significantly related to adolescent sexual values or virginity status (Dilorio et al. 1999). Youths who talked to their parents about delaying sexual activity and were taught at home how to say no to sex were less likely to have experienced intercourse than their peers (Aspy et al. 2007). Adolescents who perceived that their parents opposed premarital sex were less likely to be sexually active than adolescents whose parents had more permissive attitudes (Kirby 2002; Weinstein and Thornton 1989). Parental sexuality education may be protective. Level of protection may vary depending on what the parents and children talk about. To advance this area, the current study examined specific education topics and risky sexual behaviors among a representative sample.

\section{Theoretical Framework}

Reference group theory (Lefkowitz et al. 2004; Thornton and Camburn 1989) and the protection-risk model (Jessor et al. 2003; Turbin et al. 2006) guided this research. As applied to this study, reference group theory suggests that young people will reference the

Journal of Religion and Health, Vol. 49, No. 4 (December 2010): pg. 460-472. DOI. This article is (C) Springer and permission has been granted for this version to appear in e-Publications@Marquette. Springer does not grant permission for this article to be further copied/distributed or hosted elsewhere without the express permission from Springer 
principles of their religion to formulate their personal attitudes concerning human sexuality and to guide their behaviors. Within the protection-risk model, the presence of protective factors increases the likelihood that youths will engage in health-promoting behaviors and avoid those that are health-compromising (Turbin et al. 2006). Protective factors are protective because they provide models of health-enhancing behaviors, have sanctions against healthcompromising behaviors, and foster a supportive social environment. Even when exposed to risk, high protective factors attenuate that exposure, thereby lessening the impact from risk (Turbin et al. 2006). In this study, religiosity, formal and parental sexuality education, and two-parent families were hypothesized to be protective against risky sexual behaviors.

The purpose of this study was to investigate the association of religiosity, formal and parental sexual education, and presence of a two-parent family with risky sexual behaviors of male and female adolescents in the United States using a nationally representative sample. Based on theory and existing empirical research, the following hypotheses were formulated: (a) there will be less sexual risk behaviors among adolescents who are more religious and hold religious attitudes about human sexuality, (b) there will be less sexual risk behaviors among adolescents who have participated in formal, sexual education programs and (c) there will be less sexual risk behaviors among adolescents who live with two parents and whose parents teach them about sexuality.

\section{Method}

\section{Design and Participants}

This was a cross-sectional, secondary analysis of existing data obtained from the 2002 Cycle 6 National Survey of Family Growth (NSFG). The NSFG, a periodic survey about family, gender and sexuality, is conducted by the National Center for Health Statistics (NCHS 2007). Male $(n=4,928)$ and female $(n=7,643)$ participants were selected from an area probability sample to yield a nationally representative sample. Return rate was $\sim 79 \%$. Data were gathered during confidential, in-person interviews each lasting 60-90 min. Although the dataset has no identifying variables, this study was expedited for human rights approval. 


\section{Operational Definitions of Variables}

Of 3,456 variables in the NSFG database, three were selected as dependent variables: (1) ever been sexually active, (2) number of sexual partners in a lifetime, and (3) age of sexual debut. In the dataset, being sexually active referred to heterosexual sexual intercourse. Independent variables included gender, three measures of religiosity, receipt of formal sexual education, and two parental factor measures.

The three religiosity variables were importance of religion, frequency of attendance at religious services and religious attitudes on human sexuality. Participants rated the importance of religion in their daily lives as very important, somewhat important, or not important. For analysis purposes, these responses were dichotomized into two categories, very important or not important which included somewhat and not important. Participants indicated their frequency of religious service attendance as more than once a week, once a week, 1-3 times per month, less than once a month, or never. For analysis, these responses were also collapsed into two categories. Frequent attendance at religious services included once or more times per week and infrequent attendance included three times per month or less.

Religious attitudes on sexuality (RAS) was measured by combining five items: (1) "sexual acts between two consenting adults is OK," (2) "it is OK for unmarried 16 -year-olds to have sex if there is a strong affection," (3) "it is OK for unmarried 18 -year-olds to have sex if there is a strong affection," (4) "it is OK for an unmarried women to have a child," and (5) "it is not OK for a young couple to live together unless married." Level of agreement was indicated on a scale of 1-5 with 5 being "strongly agree." Scores for four items were reversed for analysis purposes so that a higher score indicated high RAS. Responses to these five attitude items were added together to create a total score with a range of 5-25. A high total score (mean score of 15 or higher) indicated that the respondent possessed religious attitudes on sexuality. Cronbach's alpha for the RAS scale was 73.

Participants identified receipt of formal sexual education by indicating the type of education they had received including "learned how to say no to sex," or "learned methods of birth control." Those 
who had learned how to say no and birth control methods were considered to have had abstinence-plus programming, and those who only learned how to say no were considered to have had abstinenceonly programming. Those who had learned only birth control methods and those who reported no sexual education were combined into a third group. Parenting variables were two-parent family and parental sexuality education. Participants indicated whether they had resided within a two-parent family, defined in the original survey as presence of both parents (biological or adoptive) from birth to age 18 . From a list of sexual topics, respondents identified which ones they had discussed with their parents. Responses were noted as topic first mentioned, second mentioned, etc. to the fifth mentioned.

\section{Statistical Analysis}

Means, standard deviations, frequencies, and percentages were used to describe the overall population of interest and by gender as generated SPSS 15.0. To determine the association of religious activity, sexual education, and parenting practices on sexual activity, chi-square and likelihood odds ratios (OR) were used. Student $t$ tests were used to determine the differences in sexual activity with the continuous dependent variables of number of sexual partners in a lifetime. Survival analysis was utilized to determine the cumulative survival as virgins to the age of 21 (Kaplan and Meier 1958). The minimal level of statistical significance was $P \leq 0.05$.

\section{Results}

\section{Sample}

There were 3,168 adolescents and young adults ages 15-21 years $(M=18)$ in this dataset of which $53 \%(n=1,675)$ were women and $47 \%(n=1,494)$ men. Mostly, $46.5 \%$ identified various Protestant denominations as their current religion, 30\% identified Roman Catholic, $17 \%$ reported no religion and $6.5 \%$ reported other nonChristian religions. In the NSFG dataset, participants indicated their race and their Hispanic ethnicity in two separate items. The majority (73\%) were Caucasian, 19\% African American, 4\% Native American, 4\% Asian, and $0.5 \%$ Native Hawaiian or other Pacific Islander. Twenty-one percent $(n=661)$ reported Hispanic ethnicity in addition to a racial category.

Journal of Religion and Health, Vol. 49, No. 4 (December 2010): pg. 460-472. DOI. This article is (c) Springer and permission has been granted for this version to appear in e-Publications@Marquette. Springer does not grant permission for this article to be further copied/distributed or hosted elsewhere without the express permission from Springer. 
NOT THE PUBLISHED VERSION; this is the author's final, peer-reviewed manuscript. The published version may be accessed by following the link in the citation at the bottom of the page.

Most, $58.3 \%$, reported having had sex, including $58 \%$ of the men and $59 \%$ of the women. There were no significant differences on having had sex based on gender. Nor were there differences for men and women in the mean number of lifetime sexual partners. Men reported a significantly, albeit slightly, younger mean age at coitarche than women, 15.5 vs. 15.8 , respectively, $t(1,845)=3.8, P<.001$. There was no difference in the survival time to remain a virgin to the age of 21 between male and female adolescents.

\section{Religiosity}

\section{Importance of Religion}

Most ( $N=2,409$ or $76 \%$ ) of the respondents said that religion was very important to them. Those adolescents who viewed religion as very important were $27 \%$ less likely to ever have had sex compared to adolescents who did not view religion as very important ( $O R=0.73$; $95 \% \mathrm{CI}=0.67-0.86)$. Those who viewed religion as very important reported a mean of 1.9 lifetime sexual partners $(S D=2.9)$ compared to a mean of $2.9(S D=4.3)$ partners for whom religion was less important, $t(3,167)=-6.9, P<0.001$. Finally, there was a $20 \%$ survival rate as virgins at the age of 21 among the adolescents who felt that religion was very important compared to a $15 \%$ rate among adolescents who did not view religion as very important (See Table 1 ).

Table 1. Cumulative proportion of adolescents remaining a virgin at the age of 21 by importance of religion, religious service attendance, and religious attitudes on sexuality (RAS)

\begin{tabular}{|c|c|c|c|}
\hline Religiosity measure & $N$ & $\%$ Survivors as virgin & Estimated mean age of sexual debut \\
\hline \multicolumn{4}{|c|}{ Importance of religion } \\
\hline Very important & 2,409 & 20 & $17.4(95 \% \mathrm{Cl}=17.3-17.5)$ \\
\hline Not important & 760 & 15 & $16.9(95 \% \mathrm{Cl}=16.7-17.2)$ \\
\hline \multicolumn{4}{|l|}{ Service attendance } \\
\hline Frequent & 1,026 & 25 & $17.8(95 \% \mathrm{Cl}=17.6-18.0)$ \\
\hline Infrequent & 2,143 & 17 & $17.1(95 \% \mathrm{Cl}=17.0-17.2)$ \\
\hline \multicolumn{4}{|l|}{ RAS } \\
\hline High RAS & 1,180 & 34 & $18.8(95 \% \mathrm{Cl}=18.7-19.0)$ \\
\hline Low RAS & 1,989 & 8 & $17.0(95 \% \mathrm{Cl}=16.9-17.3)$ \\
\hline
\end{tabular}

Journal of Religion and Health, Vol. 49, No. 4 (December 2010): pg. 460-472. DOI. This article is (c) Springer and permission has been granted for this version to appear in e-Publications@Marquette. Springer does not grant permission for this article to be further copied/distributed or hosted elsewhere without the express permission from Springer. 


\section{Religious Services Attendance}

Approximately one-third ( $N=1,026$ or $32 \%$ ) of respondents reported frequent attendance (i.e., at least once per week) at religious services. Those adolescents who attended services frequently were $46 \%$ less likely to ever have had sex compared to adolescents who attended services less frequently or not at all (OR $=0.55 ; 95 \% \mathrm{CI}=$ 0.49-0.63). Those who attended religious services frequently had significantly fewer lifetime sexual partners than less frequent attenders $(M=1.2, \mathrm{SD}=2.1$ vs. $M=2.6, \mathrm{SD}=3.6$, respectively $), t(3,167)=$ $-11.8, P<0.001$. Frequent attenders had a $25 \%$ survival rate as virgins at the age of 21 compared to a $17 \%$ rate among those who attended less often.

\section{Religious Attitudes on Sexuality (RAS)}

A minority of the respondents ( $N=1,180$ or $37 \%)$ had high attitude scores indicating that they held RAS. Those adolescents who held religious attitudes on sexuality were $54 \%$ less likely to ever have had sex compared to adolescents who had less religious attitudes on human sexuality $(\mathrm{OR}=0.46 ; 95 \% \mathrm{CI}=0.41-0.51)$. Those who held RAS had significantly fewer lifetime sexual partners $(M=1.2, \mathrm{SD}=$ 2.9 vs. $M=2.7, S D=3.4$ ) compared to those adolescents who held less RAS, $t(3,167)=13.0, P<0.001$. Those adolescents who had RAS had a $34 \%$ survival as virgins at the age of 21 compared to only $8 \%$ for those who did not hold RAS.

\section{Sexuality Education}

Of the 3,169 respondents, $2,285(72 \%)$ responded to the item regarding sexual education. The majority of these respondents $(62 \%$, $N=1,423)$ reported that they had had abstinence-plus education. One-fifth $(22 \%, N=493)$ attended abstinence-only, and the remaining $16 \%(N=369)$ learned methods of birth control only or about neither topic. To evaluate the influence of sexuality education, the analysis included the differences between these three groups as well as comparing all teens who learned about abstinence (abstinenceonly and abstinence-plus) to those who had not. Teens who had had abstinence-only and abstinence-plus education were equally likely to have had sex. However, those teens whose education had included abstinence (i.e., abstinence alone and abstinence with birth control) 
were $17 \%$ less likely to ever have had sex than those who had not formally learned how to say no ( $O R=0.83 ; 95 \% C I=0.73-0.95)$. A one-way ANOVA revealed significant differences in number of lifetime partners between the three groups. Those who reported abstinenceonly education had the fewest partners $(M=1.3, \mathrm{SD}=2.5)$, compared to abstinence-plus $(M=1.7, \mathrm{SD}=3)$ and to those who either had no sexual education or had learned about birth control only $(M=2.1, \mathrm{SD}$ = 3), $F(2)=7.5, P<0.001$. There was no difference in the survival time to remain as virgins at the age of 21 between youths who had or who had not received education on abstinence.

Of interest, 265 participants ( $8.4 \%$ of the total) indicated that they had taken a virginity pledge. These 'pledged' participants were $60 \%$ less likely to ever have had sex compared to adolescents who did not take a pledge $(\mathrm{OR}=0.4 ; 95 \% \mathrm{CI}=0.29-0.52)$. Pledged participants also had significantly fewer lifetime sexual partners than their peers $(M=0.7, S D=1.7$ vs. $M=1.8, S D=3$, respectively), $t(2,283)=5.9, P<0.001$. Adolescents who pledged to remain a virgin had a $47 \%$ survival rate as virgins at the age of 21 compared to only $28 \%$ among adolescents who did not take a pledge (see Table 2 for mean survival ages).

Table 2. Cumulative proportion of adolescents remaining a virgin at the age of 21 by formal and parental sexual education and presence of two-parent family

\begin{tabular}{||l||l||l|l||}
\hline Interaction variable & $\boldsymbol{N}$ & \% Survivors as virgin & Estimated mean age of sexual debut \\
\hline Formal sexual education & 1,675 & 26 & $17.6(95 \% \mathrm{Cl}=17.4-17.7)$ \\
\hline \hline Learned to say no & \multicolumn{2}{|l||}{} \\
\hline \hline Did not learn to say no & 295 & 25 & $17.1(95 \% \mathrm{Cl}=16.8-17.4)$ \\
\hline \hline Virginity pledge & 265 & 47 & $17.6(95 \% \mathrm{Cl}=17.3-17.9)$ \\
\hline \hline Pledged & 2,020 & 28 & $17.1(95 \% \mathrm{Cl}=17.0-17.2)$ \\
\hline \hline No pledge & 1,806 & 22 & $17.5(95 \% \mathrm{Cl}=17.4-17.7)$ \\
\hline Family structure & 1,363 & 14 & $17.0(96 \% \mathrm{Cl}=16.8-17.1)$ \\
\hline \hline Two parent & 1,038 & 31 & $17.4(95 \% \mathrm{Cl}=17.2-17.6)$ \\
\hline \hline Non-two parent & 1,247 & 29 & $17.1(95 \% \mathrm{Cl}=16.9-17.2)$ \\
\hline Parental sexual education &
\end{tabular}

Journal of Religion and Health, Vol. 49, No. 4 (December 2010): pg. 460-472. DOI. This article is (c) Springer and permission has been granted for this version to appear in e-Publications@Marquette. Springer does not grant permission for this article to be further copied/distributed or hosted elsewhere without the express permission from Springer. 
NOT THE PUBLISHED VERSION; this is the author's final, peer-reviewed manuscript. The published version may be accessed by following the link in the citation at the bottom of the page.

\section{Parental Factors}

Those adolescents who lived in a two-parent family from birth to the age of 18 were $14 \%$ less likely to ever have had sex compared to those who did not $(\mathrm{CI}=0.74-0.95, P<0.001)$ and had significantly fewer lifetime sexual partners $(M=1.8, \mathrm{SD}=2.8$ vs. $M=2.6, \mathrm{SD}$ $3.8), t(3,167)=6.6, P<0.001$. Adolescents from a two-parent family had a virgin survival rate of $22 \%$ at the age of 21 compared to $14 \%$ for adolescents from single-parent households.

Respondents identified five sexual education topics that they discussed with their parents. How to say no to sex was the most frequently first-mentioned topic ( $45 \%)$, followed by none of the above $(31 \%)$, methods of birth control $(11 \%)$, sexually transmitted diseases $(8 \%)$, how to use a condom $(4 \%)$, and where to get birth control $(1 \%)$. Those who identified how to say no to sex as the first topic they had talked to their parents about were $15 \%$ less likely to ever have had sex $(O R=0.85 ; 95 \% C I=0.77-0.95)$ and had fewer lifetime sexual partners than those who mentioned other topics first $(M=1.4$, $\mathrm{SD}=2.5$ vs. $M=1.9, \mathrm{SD}=3.2$, respectively) $t(2,283)=3.8, P<$ 0.001 . Rates of survival as a virgin to age 21 were essentially equivalent for adolescents whose parents promoted abstinence and those who did not.

\section{Discussion}

In this analysis of data from the NSFG, religiosity had an inverse relationship with sexual risk behaviors. As hypothesized, youths with increased importance of religion, more frequent religious services attendance and more religious sexual attitudes were more likely to delay intercourse and to have fewer sexual partners. In particular, frequency of religious services attendance and having RAS had more robust association with sexual activity than just holding religion as very important. These findings were in concert with findings from other studies (Kirby 2002; Rostosky et al. 2004) including a recent study of a subset of Latino adolescents from the NSFG 2002 dataset (Edwards et al. 2008). The findings regarding sexual attitudes- that more religious attitudes were related to less sexual risk behaviorssupported what had been alluded to, but not clearly identified, in other studies (Fehring et al. 1998; Lefkowitz et al. 2004; Thornton and Camburn 1989).

Journal of Religion and Health, Vol. 49, No. 4 (December 2010): pg. 460-472. DOI. This article is (c) Springer and permission has been granted for this version to appear in e-Publications@Marquette. Springer does not grant permission for this article to be further copied/distributed or hosted elsewhere without the express permission from Springer. 
NOT THE PUBLISHED VERSION; this is the author's final, peer-reviewed manuscript. The published version may be accessed by following the link in the citation at the bottom of the page.

While these results supported the protective nature of religiosity in terms of decreasing adolescent sexual involvement, they also identified that most youths in this dataset were not highly religious. Of the religiosity variables, the largest percentage of respondents indicated that religion was very important, but this was the weakest of the three variables in terms of decreasing sexual risk behaviors. Holding RAS appeared to be the most protective religiosity variable in terms of decreasing sexual risk; however, a minority of respondents held these values. Religiosity appears to be a potent, although not universal, protective factor for youths. As suggested by reference group theory, the extent to which religion influences attitudes and behaviors of adolescents may depend upon the specific doctrine of the churches, i.e., what youths are being taught about human sexuality as well as how socially integrated the teens are within their religious institutions (Thornton and Camburn 1989). The protective nature of religiosity may be waning as recent studies have indicated that religious sexual values are presently not as clearly expressed in formal religions as in the past and even when they are expressed, younger persons do not hold to the tenets of their faith on human sexuality as compared to members of older generations (D'Antonio et al. 2007; Prothero 2007).

In this study, as in another recent study that utilized NSFG data, there were no significant differences (at the $P<.05$ level) between the abstinence-only and the abstinence-plus groups in terms of ever having had sex (Kohler et al. 2008). However, in the current study, those youths who had formally learned how to say no, whether or not they had also learned about contraceptives, were less likely to have had sex and had fewer partners than those who had not learned about avoiding intercourse. These findings were consistent with some literature and provided partial support for the study's second hypothesis about sexuality education. In this study, learning about how to avoid sexual activity was associated with less risky short-term behaviors. In some studies, teaching youths how to avoid sexual activity in both abstinence- only and abstinence-plus programs has resulted in significantly increased short-term abstinence behaviors (Kirby et al. 2007). Nonetheless, in many other intervention studies, teaching youths how to avoid sex resulted in no significant increases in

Journal of Religion and Health, Vol. 49, No. 4 (December 2010): pg. 460-472. DOI. This article is (C Springer and permission has been granted for this version to appear in e-Publications@Marquette. Springer does not grant permission for this article to be further copied/distributed or hosted elsewhere without the express permission from Springer. 
abstinence behaviors (DiCenso et al. 2002; Kirby et al. 2007). A variety of reasons have been identified to explain why these interventions have failed to yield increases in abstinence behaviors. Yet the need to help youths to decrease their sexual risks remains high. If helping youths to avoid sexual risk behaviors is truly a national priority, then new approaches are urgently needed.

The results of this study provided support for the third hypothesis and reflected the predominant finding in the literature that those who lived with two parents experienced less sexual risk behaviors (Aspy et al. 2007; Blum et al. 2000; Kinsman et al. 1998; Kirby 2002; Lammers et al. 2000; Raine et al. 1999). In the current study, the most frequently first- mentioned topic of parental sexual education was how to avoid having sex. In this study, as in others, speaking with parents about abstinence was associated with decreased sexual risk behaviors (Dilorio et al. 1999; Aspy et al. 2007).

Finally, this analysis revealed no significant differences between men and women on the measures of sexual risk behaviors. In past studies, men have reported a higher frequency of initiating sex during adolescence, and higher frequency of engaging in vaginal sexual intercourse after coitarche than women so that adolescent males appeared to be more sexually active than their female peers (Benson and Torpy 1995; Lammers et al. 2000; Miller et al. 1998; Raine et al. 1999; Sheeran et al. 1993; Weinstein and Thornton 1989). However, recent representative national data from the 2007 Youth Risk Behavior Survey (YRBS), revealed a different picture. By 12th grade, adolescent girls reported more sexual activity (higher incidences of initiation and current sexual activity) than boys (Centers for Disease Control and Prevention 2008). The results of this study of the NSFG data were in concert with findings of the YRBS and other current research in which female adolescents were in general just as, or slightly more, likely to be sexually active as males (Aspy et al. 2007; Eaton et al. 2006; Manlove et al. 2008; Rostosky et al. 2003). Previously, researchers concluded that male adolescents were more sexually active than females; however, data from this study and others indicate that this pattern has changed.

Journal of Religion and Health, Vol. 49, No. 4 (December 2010): pg. 460-472. DOI. This article is (c) Springer and permission has been granted for this version to appear in e-Publications@Marquette. Springer does not grant permission for this article to be further copied/distributed or hosted elsewhere without the express permission from Springer. 
NOT THE PUBLISHED VERSION; this is the author's final, peer-reviewed manuscript. The published version may be accessed by following the link in the citation at the bottom of the page.

\section{Clinical Implications}

In this study, religiosity, parental and formal sexual education, and two-parent families were all associated with decreased risky sexual behaviors among adolescents and young adults. These results provide support for interventions within these domains that are intended to assist young people to decrease their sexual risks. To more fully exploit the effects of parental factors, professionals may support family interventions that facilitate relationship development between parents in order to help sustain their partnership as there is clear evidence that living in a two-parent home is beneficial.

Interventions that facilitate relationship development between parents and children are also indicated to promote increased feelings of closeness and connection as well as to help families learn how to engage in ongoing, open conversations about sexuality. Parents may choose to discuss a variety of sexual education topics. However, it is important for parents to make it explicit that they do not approve of adolescents engaging in sexual activity. This 'simple' practice of letting one's child know about expectations for their sexual behavior has been shown to be efficacious (Aspy et al. 2007; Kirby 2002; Weinstein and Thornton 1989). Further, the influence of parental education about avoiding intercourse was strengthened when there was a close relationship between the parent and the child (Jaccard et al. 1996; Weinstein and Thornton 1989).

It is important for professionals to assess the religious beliefs and values of teenage and young adult clients and that of their parents. Most formal religions in the United States hold the value that sexual activity should only exist within a committed and covenanted relationship. Therefore, as suggested by reference group theory, those young people who hold these values in consort with their religious beliefs and have them reinforced through active participation in religious institutions will be more likely to delay or reduce their sexual activity. Professionals may be supportive of, and reinforce, the value of abstaining from sexual intercourse during adolescence for those who hold or are being raised with such values. They may also encourage families to participate together and regularly in the religion of their choice. Higher levels of family religiosity, including parents' beliefs, prayer and religious service practices, and frequency of family participation in religious activities, have contributed to decreased

Journal of Religion and Health, Vol. 49, No. 4 (December 2010): pg. 460-472. DOI. This article is (C Springer and permission has been granted for this version to appear in e-Publications@Marquette. Springer does not grant permission for this article to be further copied/distributed or hosted elsewhere without the express permission from Springer. 
sexual initiation among adolescents, older age at coitarche and indirectly to decreased sexual partners (Manlove et al. 2008).

There remains a critical need to help young people decrease their risky sexual behaviors. In this study, there was a significant relationship between formally teaching young people how to avoid sex and decreased risky behaviors. Current efforts to increase abstinence behaviors have met with limited success. However, the evidence suggests that rather than abandon efforts to help young people avoid sex, we need to find new ways to do so. Innovations in sexual risk reduction education, such as culturally tailored approaches (Villarruel et al. 2007), periodic abstinence (Haglund 2008), and increased fertility awareness (Cabezon et al. 2005), are in development and more research is indicated.

Although the 2002 NSFG data are a comprehensive populationbased dataset of the United State adolescent, there were limits to the dataset and this study. The self report of sexual activity was based on recall and may have been deflated or inflated by the participants (Eggleston et al. 2000). Another limitation was the difficulty of trying to measure religiosity using retrospective data. The measures of religiosity in this study were limited to the items included in the 2002 NSFG. Important aspects of religiosity such as faith, intrinsic religiosity, and religious well-being were not assessed. Similarly, the depth of measurement of the influences of having a two-parent family, and formal and parental sexuality education were limited by dichotomous variables and did not completely capture the dynamics of these phenomena.

\section{Conclusion}

This analysis of data from the 2002 NSFG provided some evidence for the positive association of religiosity, and in particular religious attitudes on human sexuality, in helping young people to reduce risky sexual behaviors. Having a two-parent family and parents who encouraged their children to avoid having sex were also associated with a decrease in sexual exposures. Finally, having been formally taught how to say no to sex was related to less risky sexual behaviors. Further research is needed to verify these results and to see if there are trends in these relationships.

Journal of Religion and Health, Vol. 49, No. 4 (December 2010): pg. 460-472. DOI. This article is (c) Springer and permission has been granted for this version to appear in e-Publications@Marquette. Springer does not grant permission for this article to be further copied/distributed or hosted elsewhere without the express permission from Springer. 
NOT THE PUBLISHED VERSION; this is the author's final, peer-reviewed manuscript. The published version may be accessed by following the link in the citation at the bottom of the page.

\section{References}

Aspy, C., Vesely, S., Oman, R., Rodine, S., Marshall, L., \& McLeroy, K. (2007). Parental communication and youth sexual behavior. Journal of Adolescence, 30, 449-466.

Benson, M., \& Torpy, E. (1995). Sexual behavior in junior high school students. Obstetrics and Gynecology, 85, 279-284.

Blum, R., Beuhring, T., Shew, M., Bearinger, L., Sieving, R., \& Resnick, M. (2000). The effects of race/ethnicity, income, and family structure on adolescent risk behaviors. American Journal of Public Health, 90, 1879-1884.

Cabezon, C., Vigil, P., Rojas, I., Leiva, M., Riquelme, R., Aranda, W., et al. (2005). Adolescent pregnancy prevention: An abstinence-centered randomized controlled intervention in a Chilean public high school. The Journal of Adolescent Health, 36, 64-69.

Centers for Disease Control and Prevention. (2008). Youth risk behavior surveillance-United States, 2007. MMWR, 57(No. SS-4).

D'Antonio, W., Hoge, D., Gautier, M., \& Davidson, J. (2007). American catholics today: New realities of their faith and their church. Lenham, MD: Roman and Littlefield.

DiCenso, A., Guyatt, G., Willan, A., \& Griffith, L. (2002). Interventions to reduce unintended pregnancies among adolescents; systematic review of randomized controlled trials. British Medical Journal, 324, 14261430.

Dilorio, C., Kelley, M., \& Hockenberry-Eaton, M. (1999). Communication about sexual issues: Mothers, fathers, and friends. The Journal of Adolescent Health, 24, 181-189.

Eaton, D., Kann, L., Kinchen, S., Ross, J., Hawkins, J., Harris, W., et al. (2006). Youth risk behavior surveillance-United States, 2005. MMWR, 55(No. SS-5).

Edwards, L., Fehring, R., Jarrett, K., \& Haglund, K. (2008). The influence of religiosity, gender, \& language preference acculturation on sexual activity among Latino/a adolescents. Hispanic Journal of Behavioral Sciences, 30, 447-462.

Eggleston, E., Leitch, J., \& Jackson, J. (2000). Consistency of self-reports of sexual activity among young adolescents in Jamaica. International Family Planning Perspectives, 7, 102-112.

Journal of Religion and Health, Vol. 49, No. 4 (December 2010): pg. 460-472. DOI. This article is (c) Springer and permission has been granted for this version to appear in e-Publications@Marquette. Springer does not grant permission for this article to be further copied/distributed or hosted elsewhere without the express permission from Springer. 
NOT THE PUBLISHED VERSION; this is the author's final, peer-reviewed manuscript. The published version may be accessed by following the link in the citation at the bottom of the page.

Fehring, R., Cheever, K., German, K., \& Philpot, C. (1998). Religiosity and sexual activity among older adolescents. Journal of Religion and Health, 37, 229-247.

Haglund, K. (2008). Reducing sexual risks with practice of periodic abstinence. JOGNN. Journal of Obstetric, Gynecologic, and Neonatal Nursing, 37, 647-656.

Holder, D., Durant, R., Harris, T., Daniel, J., Obeidallah, D., \& Goodman, E. (2000). The association between adolescent spirituality and voluntary sexual activity. The Journal of Adolescent Health, 26, 295-302.

Jaccard, J., Dittus, P., \& Gordon, V. (1996). Maternal correlates of adolescent sexual and contraceptive behavior. Family Planning Perspectives, 28, 159-165.

Jessor, R., Turbin, M., Costa, F., Dong, Q., Zhang, H., \& Wang, C. (2003). Adolescent problem behavior in China and the United States: A crossnational study of psychosocial protective factors. Journal of Research on Adolescence, 13, 329-360.

Kaplan, E., \& Meier, P. (1958). Nonparametric estimation from incomplete observations. Journal of the American Statistical Association, 53, 457485.

Kinsman, S., Romer, D., Furstenberg, F., \& Schwarz, D. (1998). Early sexual initiation: The role of peer norms. Pediatrics, 102, 1185-1192.

Kirby, D. (2002). Antecedents of adolescent initiation of sex, contraceptive use and pregnancy. American Journal of Health Behavior, 26, 473485.

Kirby, D., Laris, B., \& Rolleri, L. (2007). Sex and HIV education programs: Their impact on sexual behaviors of young people throughout the world. The Journal of Adolescent Health, 40, 206-217.

Kohler, P., Manhart, L., \& Lafferty, W. (2008). Abstinence-only and comprehensive sex education and the initiation of sexual activity and teen pregnancy. The Journal of Adolescent Health, 42, 344-351.

Lammers, C., Ireland, M., Resnick, M., \& Blum, R. (2000). Influences on adolescents' decision to postpone onset of sexual intercourse: A survival analysis of virginity among youths aged 13 to 18 years. The Journal of Adolescent Health, 26, 42-48.

Lefkowitz, E., Gillen, M., Shearer, C., \& Boone, T. (2004). Religiosity, sexual behavior, and sexual attitudes during emerging adulthood. Journal of Sex Research, 41, 150-159.

Journal of Religion and Health, Vol. 49, No. 4 (December 2010): pg. 460-472. DOI. This article is (c) Springer and permission has been granted for this version to appear in e-Publications@Marquette. Springer does not grant permission for this article to be further copied/distributed or hosted elsewhere without the express permission from Springer. 
NOT THE PUBLISHED VERSION; this is the author's final, peer-reviewed manuscript. The published version may be accessed by following the link in the citation at the bottom of the page.

Manlove, J., Logan, C., Moore, K., \& Ikramullah, E. (2008). Pathways from family religiosity to adolescent sexual activity and contraceptive use. Perspectives on Sexual and Reproductive Health, 40, 105-117.

McCree, D., Wingood, G., DiClemente, R., Davies, S., \& Harrington, K. (2003). Religiosity and risky sexual behavior in African-American adolescent females. The Journal of Adolescent Health, 33, 2-8.

Menacker, F., Martin, J., MacDorman, M., \& Ventura, S. (2004). Births to 1014-year-old mothers, 1990-2002: Trends and health outcomes. National Vital Statistics Reports, 53, 1-20.

Miller, K., Sabo, D., Farrell, M., Barnes, G., \& Melnick, M. (1998). Athletic participation and sexual behavior in adolescents: The different worlds of boys and girls. Journal of Health and Social Behavior, 39, 108-123.

Mott, F., Fondell, M., Hu, P., Kowaleski-Jones, L., \& Menaghan, E. (1996). The determinants of first sex by age 14 in a high-risk adolescent population. Family Planning Perspectives, 28, 13-18.

NCHS. (2007). National survey of family growth. Retrieved October 1, 2008 from http://www.cdc.gov/nchs/nsfg.htm.

Nonnemaker, J., McNeely, C., \& Blum, R. (2003). Public and private domains of religiosity and adolescent health risk behaviors: Evidence from the National Longitudinal Study of Adolescent Health. Social Science \& Medicine, 57, 2049-2054.

Prothero, S. (2007). Worshipping in ignorance. The Chronicle Review, March 16: B6-B7.

Raine, T., Jenkins, R., Aarons, S., Woodward, K., Fairfax, J., El-Khorazaty, M., et al. (1999). Sociodemographic correlates of virginity in seventhgrade black and Latino students. Journal of Adolescent Health, 24, 304-312.

Romer, D., Stanton, B., Galbraith, J., Feigelman, S., Black, M., \& Li, X. (1999). Parental influence on adolescent sexual behavior in highpoverty settings. Archives of Pediatric and Adolescent Medicine, 153, 1055-1062.

Rostosky, S., Regnerus, M., \& Wright, M. (2003). Coital debut: The role of religiosity and sex attitudes in the add health survey. The Journal of Sex Research, 40, 358-367.

Rostosky, S., Wilcox, B., Wright, M., \& Randall, B. (2004). The impact of religiosity on adolescent sexual behavior: A review of the evidence. Journal of Adolescent Research, 19, 677-697.

Journal of Religion and Health, Vol. 49, No. 4 (December 2010): pg. 460-472. DOI. This article is (c) Springer and permission has been granted for this version to appear in e-Publications@Marquette. Springer does not grant permission for this article to be further copied/distributed or hosted elsewhere without the express permission from Springer. 
NOT THE PUBLISHED VERSION; this is the author's final, peer-reviewed manuscript. The published version may be accessed by following the link in the citation at the bottom of the page.

Sheeran, P., Abrams, D., Abraham, C., \& Spears, R. (1993). Religiosity and adolescents' premarital sexual attitudes and behavior: An empirical study of conceptual issues. European Journal of Social Psychology, 23, 39-52.

Thornton, A., \& Camburn, D. (1989). Religious participation and adolescent sexual behavior and attitudes. Journal of Marriage and the Family, 51, 641-653.

Turbin, M., Jessor, R., Costa, F., Dong, Q., Zhang, H., \& Wang, C. (2006). Protective and risk factors in health-enhancing behavior among adolescents in China and the United States: Does social context matter? Health Psychology, 25, 445-454.

Ventura, S., Abma, J., Mosher, W., \& Henshaw, S. (2007). Recent trends in teenage pregnancy in the United States, 1990-2002. Retrieved October 1, 2008 from http://www.cdc.gov/nchs/products/pubs/pubd/hestats/teenpreg19902002/teenpreg1990- 2002.htm.

Villarruel, A., Jemmott, J., \& Jemmott, L. (2007). A randomized controlled trial testing an HIV prevention intervention for Latino youth. Archives of Pediatric and Adolescent Medicine, 160, 772-777.

Weinstein, M., \& Thornton, A. (1989). Mother-child relations and adolescent sexual attitudes and behavior. Demography, 26, 563-577.

Weinstock, H., Berman, S., \& Cates, W. (2004). Sexually transmitted diseases among American youth: Incidence and prevalence estimates, 2000. Perspectives on Sexual and Reproductive Health, 36, 6-10.

Young, M., \& Penhollow, T. (2006). The impact of abstinence education: What does the research say? American Journal of Health Education, 37, 194-202.

\section{About the Authors}

Kristin A. Haglund : College of Nursing, Marquette University Milwaukee, WI.

E-mail: Kristin.haglund@marquette.edu

Journal of Religion and Health, Vol. 49, No. 4 (December 2010): pg. 460-472. DOI. This article is (c) Springer and permission has been granted for this version to appear in e-Publications@Marquette. Springer does not grant permission for this article to be further copied/distributed or hosted elsewhere without the express permission from Springer. 